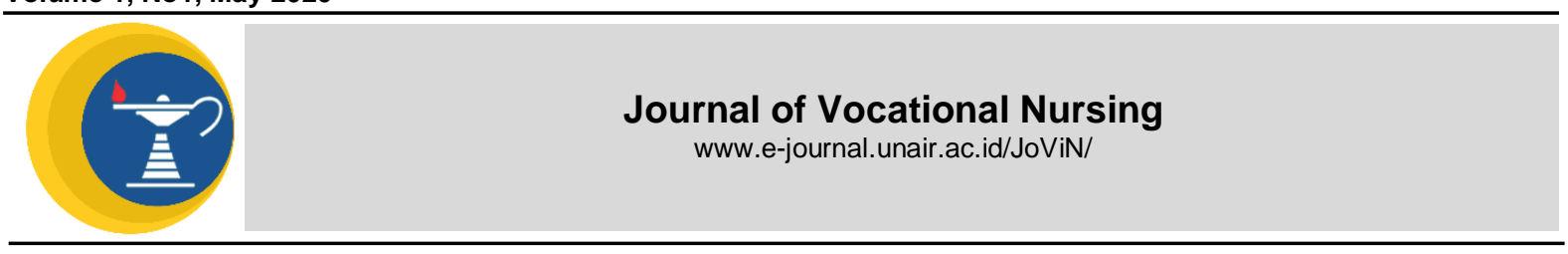

\title{
EFFECT OF REPRODUCTIVE HEALTH EDUCATION ON ADOLESCENT KNOWLEDGE LEVEL ABOUT UNWANTED PREGNANCY IN PALALANGON VILLAGE, CIANJUR REGENCY
}

Research Report

Lidya Natalia1 ${ }^{1}$ Wintari Hariningsih ${ }^{2}$ and Isna Tresna Majiah ${ }^{3}$

1,2,3 STIK Immanuel Bandung

\section{ABSTRACT}

Introduction: Adolescence is one of the stages of life. Adolescents hope that the future of the nation needs to be taken care of physically and mentally and socially as a whole (Law No. 61/2014 about Reproductive Health), as well as all matters relating to the system and functions and processes of reproduction. In Indonesia the incidence of unwanted pregnancy in adolescents has a percentage of $17 \%$. Adolescent reproductive health education about unwanted pregnancy is very important to be known by adolescents as one of the preventions of unwanted pregnancy. The purpose of this study was to analyze the effect of reproductive health education on adolescent knowledge level about unwanted pregnancy in adolescent Palalangon.

Methods : The study design uses a pre-experimental design one group pretest-posttest design, using a purposive sampling technique and obtained a total sampling of 39 respondents. The method of data collection is done by using a questionnaire statement totaling 25 items.

Results : The results showed that 38 respondents (97.4\%) before the health education program was knowledgeable and less than 1 person (2.6\%) knowledgeable, whereas after health education all respondents had a good knowledge with a percentage (100\%). The conclusion of Wilcoxon's statistical test analysis results obtained sig (0.00) <sig (0.05) which means that there is an effect of adolescent reproductive health education between knowledge before and after health education.

Conclusion: Health care workers are expected to be able to carry out health education specifically on adolescent reproductive health as one of the preventions of unwanted pregnancy problems among adolescents
ARTICLE INFO

Recived 29 December 2019

Accepted 12 May 2020

Online 29 May 2020

*Correspondence:

Lidya Natalia

*Email:

natalia.lidya17@gmail.com

Keywords:

Adolescent, Health Education,

Knowledge, Unwanted

Pregnancy

\section{INTRODUCTION}

Adolescence is one of the stages in life. Teens nation's future expectations need to be kept physically mental health and social welfare as a whole, as well as all matters relating to the systems, functions, and processes of reproduction ( Law no . 61/2014 on Health Reproduks ) Symptoms often we see and then raises problems are: premarital sex, adolescent unpreparedness to overcome the pregnancy that results, has triggered a broad problem: abortion, cruelty to the baby born or problems in child care (Soetjiningsih, 2007). The analysis result of the Directorate General of Public Health of the Ministry of Health and Social Welfare and the Republic of Indonesia Social
Welfare (2015), shows that the condition of reproductive health in Indonesia is still not as expected when compared to the situation in other ASEAN countries. Indonesia is still far behind in aspects of reproductive health including adolescent reproductive health (BKKBN, 2015).

Possible reproductive health problems experienced by adolescents include unwanted pregnancy, abortion, sexually transmitted diseases (STDs), sexual violence, and the problem of limited access to information and health services. The limited access to information for Indonesian youth regarding reproductive health in which sexuality is caused because Indonesian people still think that 
sexuality is taboo and does not deserve to be discussed openly. Usually parents feel reluctant to provide an explanation of reproductive health and sexuality issues to their children who are starting to grow into adolescents, and adolescents also tend to feel ashamed to ask openly to their parents (BKKBN, 2015). The main problem experienced by Indonesian teenagers is ignorance of the actions that must be taken in connection with developments that are being experienced, especially adolescent reproductive health issues. This is indicated by the still low knowledge of adolescents about reproductive health. Adolescent girls who know about the fertile period only reached $29 \%$ while male adolescents amounted to $32.3 \%$. Adolescent girls and boys who know the risk of pregnancy if they have sexual intercourse for the first time reach $49.5 \%$ and $45 \%$, respectively. Adolescent girls and boys aged 14-19 years who claimed to have friends had had sexual relations before marriage each reached $34.7 \%$ and $30.9 \%$ 61/2014 About Reproductive Health while adolescent girls and adolescent boys aged 20-24 years who claimed to have friends had had sexual relations before marriage, respectively $48.6 \%$ and $46.5 \%$ (BKKBN, 2015).

Another problem in Sarwono (2011) says that in developed countries such as the United States, the teenage pregnancy rate (ages 15-19) is 95/1000 with an abortion rate of $52 / 1000$. This figure is very high compared to England (45/1000 pregnancy, 30/1000 abortion), Canada (45/1000 pregnancy, 27/1000 abortion), France (44/1000 pregnancy, 27/1000 abortion), Sweden (35 pregnancy / 1000 , abortion 15/1000), and the Netherlands (15/1000 pregnant, abortion 10/1000). The number of adolescents aged $10-24$ years in Indonesia is around 64 million or $28.64 \%$ of the total population. Around 1 million young men (5\%) and 200 thousand young women (1\%) openly stated that they had had sexual relations (Sarwono, 2011). Meanwhile according to the results of the Basic Health Research (RISKESDAS) in 2013 the proportion of teenagers in Indonesia itself at the age of 15-19 years who experienced pregnancy was $1.97 \%$ and according to the IDHS (2013) in Indonesia, the incidence of CERD was high at $17 \%$. Based on the results of preliminary studies carried out by researchers on 30 April 2015-02 May 2015 in Palalangon, Kertajaya village, Cianjur subdistrict, Ciranjang regency by initial interview to 10 respondents with the result that all the teenagers interviewed, expressed ever kissing her lover and 6 out of 10 teenagers admit having had premarital sex with their boyfriends. All respondents said they knew about the dangers of reproductive health but still had premarital sex which meant that all respondents did not understand and were not aware of the dangers of reproductive health.

Previous research conducted by Nydia in 2012 about the effects of education on education on the level of reproductive health knowledge in adolescent students at Kristern Gergaji junior high school using a quasiexperimental one group pretest-posttest design. The results of this study there are significant differences in the level of knowledge after counseling. Significant differences in the level of knowledge exist on the topics of anatomy and physiology, as well as sexually transmitted diseases (STDs) and HIV / AIDS.

Another study conducted by Frisa Buzarudina in 2013 about the effectiveness of adolescent reproductive health counseling on the knowledge level at Senior High School 6 East Pontianak by using a quasiexperimental method with a one group pretestposttest design conducted on 87 respondents shows that there is a significant difference between the score before counseling with the score after counseling.

The things above show the importance of health education to prevent reproductive health problems, especially in adolescents. Research shows that adolescents in developing countries desperately need reproductive health education. Adolescents have the risk of having premarital sexual relations intentionally or unintentionally. Therefore, the most appropriate time to provide reproductive health education is during adolescence. This will also help teenagers to find out how to deal with unwanted pregnancy problems due to premarital sexual relations. In addition, WHO stresses the importance of reproductive health education as a teenager. This age is the golden age for the establishment of a strong foundation of reproductive health, so that they can prepare them to make safer and wiser sexual decisions (WHO, 2014 ). This study was aimed to explain the effect of reproductive health education on adolescent knowledge level about unwanted pregnancy in Palalangon Village, Cianjur Regency.

\section{MATERIALS AND METHODS}

This type of research used in this study is quasy pre-experiment using one group prepost test design. The reason for using this type of research because it is in accordance with the research objectives is to analyze the effect of health education on the level of knowledge of adolescents about Unwanted Pregnancy in adolescents in Palalangon, Cianjur. The population in this study amounted to 207 
adolescents who were registered as Palalangon youth congregations. The sample in this study was taken using a purposive sampling technique and 39 respondents were obtained with inclusion and exclusion criteria. The instrument in this study used 25 items in the form of questionnaire statements that have been tested for validity $(0.361)$ and reliability. Data collection procedures in this study were assisted by 2 sources

The first stage in data collection is the pretest then health education interventions in the form of counseling and the final stage is as a posttest.
Univariate analysis for adolescent knowledge about unwanted pregnancy is carried out using the formula of frequency distribution and bivariate analysis performed to see the effect of using a non-parametric statistical analysis Wilcoxon because the data are not normally distributed. This research is inseparable from research ethics by taking into account the usefulness of research, explaining that research does not contain harmful, lifethreatening, and life-threatening elements and researchers maintain the confidentiality of respondents' identities. The research was carried out in Palalangon Village, Cianjur Regency on 09 Maret - 16 August 2015.

\section{RESULTS}

\section{Characteristics of Respondents}

Table 1 Frequency Distribution Characteristics of Respondents

\begin{tabular}{cccc}
\hline No & Characteristic & Frequency & Percentage \\
\hline 1 & Sex : & & 54 \\
& Female & 21 & 46 \\
2 & Male & 18 & 12,82 \\
& Education : & 5 & 82,05 \\
& Junior high school & 32 & 5,13 \\
\hline & Senior high school & 2 & 100 \\
\hline
\end{tabular}

In this study the respondents in the study sample were 39 people and 54\% participated in the female sex and $46 \%$ were male. Respondents aged 18-21 years with 32 people in high school education, 5 people in junior high school, and 2 people in college. All respondents have never received information in the form of health education/counseling for the past 6 months.

Table 2 Frequency Distribution of Unwanted Pregnancy Knowledge Before Reproductive Health Education

\begin{tabular}{|c|c|c|c|}
\hline No & Knowledge & Frequency & Percentage \\
\hline 1 & Good & 0 & 0 \\
\hline 2 & Enough & 38 & 97,4 \\
\hline 3 & Less & 1 & 2,6 \\
\hline \multicolumn{2}{|c|}{ Total } & 30 & 100 \\
\hline
\end{tabular}

Table 2 shows that almost all respondents had sufficient knowledge about unwanted pregnancy before conducting reproductive health education.

Table 3 Frequency Distribution of of Unwanted Pregnancy Knowledge After Reproductive Health Education

\begin{tabular}{|c|c|c|c|}
\hline No & Jobs & Frequency & Percentage \\
\hline 1 & Good & 30 & 100 \\
\hline 2 & Enough & 0 & 0 \\
\hline 3 & Less & 0 & 0 \\
\hline \multicolumn{2}{|c|}{ Total } & 30 & 100 \\
\hline
\end{tabular}

Table 3 shows that all respondents had good knowledge of unwanted pregnancy after reproductive health education. 
Table 4 Saphiro Wilk Data Normality Test Results

\begin{tabular}{ccccc}
\hline & & & Saphiro wilk & \\
\cline { 2 - 5 } & & St. & Sig. & Conclusion \\
\hline Pre test & 847 & 0,00 & Abnormal \\
Post test & 632 & 0,00 & Abnormal \\
\hline & Total & & 30 & 100 \\
\hline
\end{tabular}

Table 4 above shows the results of normality testing data using Saphiro-Wilk statistical analysis can be seen that the p-value obtained from each group ( Pretest $(0.00)$ and Posttest $(0.00)$ is below 0.05 . This shows that the distribution of data used abnormally so for the bivariate analysis the Wilcoxon nonparametric analysis was used .

Table 5 Effect of Reproductive Health Education on Adolescent Knowledge Levels about Unwanted Pregnancy

\begin{tabular}{cccc}
\hline No & & Pre Test & Post Test \\
\hline 1 & Mean & 63,69 & 97,33 \\
2 & Std. Deviation & 4,889 & 2,950 \\
3 & Min & 48 & 92 \\
4 & Max & 72 & 100 \\
\hline & $p$-value & & 0,00 \\
\hline
\end{tabular}

Table 5, it is known that the mean score of adolescent knowledge about Unwanted Pregnancy has increased to (97.33) after getting reproductive health education with a standard deviation $(2,950)$ and from the Wilcoxon statistical test results obtained $p$-Value $(0.00)<(0.05)$ so that it can be concluded that there is a significant influence between reproductive health education on adolescents knowledge level about unwanted pregnancy in Palalangon, Cianjur Regency.

\section{DISCUSSION}

\section{Adolescent Knowledge About Unwanted Pregnancy Before Being Given Reproductive Health Education ( Pre-test)}

Univariate analysis results can be seen that the frequency distribution of adolescent knowledge before being given reproductive health education as many as 38 adolescents (97.4\%) have sufficient knowledge about Unwanted Pregnancy and 1 teenager (2.6\%) has less knowledge about unwanted pregnancy.

The results of the above analysis are the same as a study conducted by Septiana (2014) entitled "The Effect of Reproductive Health Education on the Level of Adolescent Knowledge About Reproductive Health in Ciputat Islamic Middle School" found that (87.5\%) had sufficient knowledge and (12, 5\%) have less knowledge before being given reproductive health education regarding reproductive health.

According to Kumalasari (2008) knowledge is very influential in the future of adolescents. The existence of ease in finding various kinds of information including information relating to the problem of Unwanted Pregnancy, especially as one of the factors for the prevention of Unwanted Pregnancy in adolescents.
Factors that can be an influence on a person's knowledge are educational factors, which means the higher a person's education, the higher the knowledge he has and the more information he gets; work factors, from the work environment it can influence someone in obtaining information; the age factor, the adolescent age factor in this study shows that the development in late adolescence is an increasingly steady interest in intellectual functions, formed a sexual identity that will not change anymore, his ego seeks opportunities to unite with others and in experiences new.

Adolescent as the next generation need good knowledge to become role models of society. The lack of knowledge about reproductive health and the strong influence of westernized modernization on premarital sexual relations makes adolescents a population at risk of experiencing adolescent problems, one of which is Unwanted Pregnancy associated with adolescent growth and development that tends to be trial and error. according to the results of the Basic Health Research (RISKESDAS) in 2013, the proportion of adolescents in Indonesia themselves at the age of 15-19 years who experienced pregnancy was $(1.97 \%)$ and according to the IDHS (2007) in Indonesia, the incidence of unwanted pregnancy was high (17\%). 
In the researcher's opinion, respondents have sufficient knowledge that can be caused due to a lack of factors that influence knowledge such as education, factors. Educational factors in this study 32 respondents were still in senior high school, and the age of respondents in this study was predominantly 18 years. The knowledge factor is also influenced by interests, experience and lack of information obtained by respondents, especially information about Unwanted Pregnancy. Information obtained by respondents is only through school while in Palalangon village there is no health education in the form of regular counseling by local health workers, these factors can affect respondents' knowledge.

\section{Adolescent Knowledge About unwanted pregnancy After Being Given Reproductive Health Education ( Post-test )}

Based on univariate results it can be seen that all respondents have good knowledge about Unwanted Pregnancy with a percentage $(100 \%)$ after being given reproductive health education.

The results of research conducted by other studies conducted by Frisa Buzarudina (2013) with the title "Effectiveness of Adolescent Reproductive Health Counseling on Knowledge Levels of Students of SMAN 6, East Pontianak District" conducted on 87 respondents with a percentage obtained $(70.2 \%)$ has a level of knowledge which is good after adolescent reproductive health counseling.

According to Rogers (1974) quoted by Notoatmodjo (2003) behavior is all good human activities or activities that can be observed directly from anywhere or cannot be observed directly from outside parties. The process of increasing knowledge according to Notoatmodjo (2003), namely: 1) Awarness (awareness) where the person realizes in the sense of knowing in advance the stimulus (object); 2) Interest, namely the individual starts to pay attention and be attracted to the stimulus; 3) Evaluation (weighing) individuals will consider the pros and cons of the action on the stimulus.

In the opinion of the researcher, the increase in adolescent knowledge became good after reproductive health education was carried out because of the awareness and interest in reproductive health education provided by the speakers as well as the interest of respondents to participate in reproductive health education and supported by the existence of reproductive health education factors, namely counseling factors that convey health education material is understood by the respondents, the target factor is the focus of health education targets in this study is the late teens aged 18-21 years and the process factors that take place quite well during health education so that respondents understand and understand what is delivered by the instructor/resource person.

\section{Effect of Reproductive Health Education on Adolescent Knowledge Levels on Unwanted Pregnancy \\ Based on the bivariate results, it can be} seen that the mean results of the knowledge of young women regarding unwanted pregnancy before getting reproductive health education is (54.62) with a standard deviation (5.779) and has increased to (98.21) after getting reproductive health education with a standard deviation being $(2,922)$ and from the statistical test results obtained $p$-value $(0.00) p<(0.05)$ so that it can be concluded that there is a significant difference (sig.) Between adolescent knowledge about unwanted pregnancy before and after health education is given a reproduction of reproduction in adolescents in Palalangon, Cianjur Regency.

The results of the above analysis are the same as other studies conducted by Frisa Buzarudina in 2013 with the title "Effectiveness of Adolescent Reproductive Health Counseling on Knowledge Levels of SMAN 6 Students in East Pontianak District" using a quasiexperimental method with a one group pretestposttest design conducted at 87 respondents used the Wilcoxon test with the results obtained significance value $(\mathrm{sig})$ of $0,000(p<0.05)$. The $p$-value $<0.05$ shows that there is a significant difference between the score before counseling with the score after counseling with the percentage not good to the level of knowledge before counseling as much as $70.2 \%$ and after counseling the level of knowledge becomes good with a percentage of $39.1 \%$.

According to Notoatmodjo (2012) reproductive health education, in general can be interpreted as any planned effort to influence others, both individuals, groups, and even society. Reproductive health education can also produce significant changes or improvements to a person's knowledge, attitudes, and behavior.

In the opinion of researchers, Unwanted Pregnancy as one of the effects of premarital sexual relations carried out by teenagers both intentionally or unintentionally which usually adolescents only think of pleasure and pleasure for a moment without thinking about the subsequent effects. One factor that influences knowledge is information. Adolescents in Palalangon before conducting reproductive 
health education have sufficient knowledge due to the lack of regular visits and the implementation of health education from health workers. Positive information can help someone to form positive behavior because behavior based on good knowledge will be more lasting than behavior that is not based on knowledge. Knowledge is said to be good if someone has comprehension or can explain correctly about the material or object that is known and can interpret it correctly. Therefore, reproductive health education is very important as positive information for adolescents, basically that adolescents are a process of continuous growth and development as well as a process of transition from childhood to adulthood, so adolescents need a lot of positive information.

\section{CONCLUSION}

Based on the results of the data analysis and discussion carried out in the previous chapter, it can be concluded: respondent knowledge before health education, almost all of them had sufficient knowledge and had less knowledge. Knowledge of all respondents after health education, have good knowledge. There was the significant effect between respondents' knowledge about unwanted pregnancy before and after health education.

\section{REFERENCES}

Arikunto, Suharsimi. (2002). Prosedur Pendekatan Praktek. Edisi Revisi V. Jakarta: Rineka Cipta

(2005). Manajemen Penelitian. Edisi Revisi.Jakarta: Rineka Cipta .(2006).

Prosedur Penelitian Pendekatan Praktek. Edisi Revisi VI. Jakarta: Rineka Cipta

Ardayani, Tri. (2012). Kesehatan Reproduksi Untuk Kebidanan, Keperawatan, dan Tenaga Kesehatan. Bandung: CV Cakra

Asrori. (2004). Psikologi Remaja Perkembangan Peserta Didik, http://repository.usu.ac.id/bitstream/12 3456789/27468/2/Reference.pdf diakses pada 19 Januari 2015

BKKBN.(2001). Remaja Mengenai Dirinya. Jakarta: BKKBN

BKKBN. (2013). Refleksi Pelajar Akhir Tahun 2012-2013.

http://edukasi.kompasiana/2013/05/29/ refleksi-pelajar-akhir-tahunpelajaran2012-2013-563839.pdf diakses pada tanggal 03 April 2015
Budioro, B.(2001). Pengantar IImu Kesehatan Masyarakat, Semarang: Badan Penerbit Universitas Diponegoro

Desmita. (2006). Psikologi Perkembangan. http://library.um.ac.id/freecontents/index.php/buku/detail/psikolo gi-perkembangan-oleh-desmita31372. html diakses pada tanggal 19 Januari 2015

Departemen Kesehatan RI. (2007). Peta Kesehatan Indonesia 2007. Jakarta: Depkes RI

Dinas Kesehatan Proponsi Jawa Barat. (2004). Profil Dinas Kesehatan Jawa Barat

\section{(2009). Profil Dinas Kesehatan Jawa} Barat

Dinas Propinsi Kabupaten Cianjur (2014). Profil Dinas Kesehatan Kabupaten Cianjur tahun 2014. Bandung: Dinkes Kabupaten Cianjur

Latifah. (2010). Jurnal Kesehatan Masyarakat, http://journal.unnes.ac.id/nju/index.php /kemas diakses pada tanggal 23 januari 2015

Maulana, HDJ. (2009). Promosi Kesehatan. Jakarta: EGC

Mubarak, dkk. (2007). Promosi Kesehatan: Sebuah Proses Pengantar Proses Belajar Mengajar dalam Pendidikan. Yogyakarta: Graha Nusantara

Mubarak. (2009). IImu Kesehatan Masyarakat: Teori dan Aplikasi. Jakarta: Salemba

Mustaqim. (2008). Psikologi Pendidikan. Yogyakarta: Pustaka Belajar

Norwood, Susan Lussie. 2000. Research Strategies for Advance Practice Nurse, http://www.uk.sagepub/moulegoodma n2e/study/PDFs\%20of\%20journal\%20 articles/14\%20Lipp.pdf diakses pada tanggal 21 Januari 2015

Notoatmodjo. 2003. Pendidikan dan Perilaku Kesehatan. Jakarta: PT Rineka Cipta (2005). Metodologi Penelitian Kesehatan. Jakarta: Rineka Cipta (2007). Promosi Kesehatan Teori dan IImu Perilaku. Jakarta: Rineka Cipta (2012). Edisi Revisi. Jakarta: Rineka Cipta

Nuryati, Siti. (2011). Pengaruh Penyuluhan Kesehatan Reproduksi Terhadap Kemampuan Kognitif Remaja, http://eprints.uns.ac.id/9009/pdf diakses pada tanggal 17 Januari 2015

Nydia. (2012). Pengaruh Penyuluhan terhadap Tingkat Pengetahuan Kesehatan Reproduksi pada Remaja Siswa SMP Kristen Gergaji. http://core.ac.uk/download/pdf/117359 
58.pdf diakses pada tanggal 17 Januari 2015

Riset Kesehatan Dasar (RISKESDAS). (2010). Riset Kesehatan Dasar Tahun 2010. Jakarta: Menteri Kesehatan Republik Indonesia

Sugiyono. (2009). Metode Penelitian Pendidikan. Pendekatan Kuantitatif, Kualitatif dan R\&D. Bandung: Alfabeta (2013). Metode Penelitian Pendidikan. Pendekatan Kuantitatif, Kualitatif dan R\&D. Bandung: Alfabeta

Sarwono. (2011). Psikologi Pada Remaja Edisi Revisi. Jakarta: Gravindo Persada

Soetjiningsih. (2007). Tumbuh Kembang Remaja dan Permasalahannya. Jakarta: Sagung Seto

Tribun Jawa Barat. (2008). Profil Pendidikan, Kesehatan, Dan Sosial Remaja Kota Bandung : Masalah dan Alternatif Solusinya, http://8.Profil-PendidikanKesehatan-dan-Sosial-Remaja-KotaBandung-Masalah-dan-

Alternatifnya.pdf diakses pada tanggal 17 Mei 2015

Wasis. (2008). Pedoman Riset Praktis untuk Profesi Perawat. Jakarta: EGC

Widyastuti, dkk. (2009). Kesehatan Reproduksi. Yogyakarta: Fitramaya
Widyastuti, dkk. (2009). Kesehatan Reproduksi. Yogyakarta: Fitramaya

Widyaningsih. (2007). Kesehatan Reproduksi dan Kehidupan Generasi Muda, https://www.kesehatanreproduksi/sear chpdf diakses pada tanggal 17 Mei 2015

Wuryani, Djiwandono. (2006). Psikologi Pendidikan. Jakarta: Grasindo

World Health Organization (WHO). (2013). Seksual Bebas Pada remaja. https://www.google.com/searchpdf seksual bebas pada remaja menurut WHO diakses pada tanggal 15 Mei 2015

Zumrotin \& Lestari. (2007). ABORSI: Fakta, Kebutuhan dan Tantangan Serta Pengaruhnya dalam Profil Kesehatan Perempuan Indonesia, http://www.mitrainti.org/?=node/228 diakses pada tanggal 17 Mei 2015

WHO.(2010). World health statistics.(diakses tanggal 11 november 2018). http://www.who.int/entity/whosis/whost at/EN_WHS10_Full.pdf?ua=1. 